\title{
Adoptive cell transfer therapy for hepatocellular carcinoma
}

\author{
Renyu Zhang ${ }^{*}$, Zhao Zhang ${ }^{*}$, Zekun Liu, Ding Wei, Xiaodong Wu, Huijie Bian (ه), Zhinan Chen (ه) \\ Department of Cell Biology, National Translational Science Center for Molecular Medicine, State Key Laboratory of Cancer Biology, Fourth \\ Military Medical University, Xi'an 710032, China \\ (C) The Author(s) 2019. This article is published with open access at link.springer.com and journal.hep.com.cn
}

\begin{abstract}
Hepatocellular carcinoma (HCC) is one of the most common cancers worldwide. This malignancy is associated with poor prognosis and high mortality. Novel approaches for prolonging the overall survival of patients with advanced HCC are urgently needed. The antitumor activities of adoptive cell transfer therapy (ACT), such as strategies based on tumor-infiltrating lymphocytes and cytokine-induced killer cells, are more effective than those of traditional strategies. Currently, chimeric antigen receptor T-cell (CAR-T) immunotherapy has achieved numerous breakthroughs in the treatment of hematological malignancies, including relapsed or refractory lymphoblastic leukemia and refractory large B-cell lymphoma. Nevertheless, this approach only provides a modest benefit in the treatment of solid tumors. The clinical results of CAR-T immunotherapy for HCC that could be obtained at present are limited. Some published studies have demonstrated that CAR-T could inhibit tumor growth and cause severe side effects. In this review, we summarized the current application of ACT, the challenges encountered by CAR-T technology in HCC treatment, and some possible strategies for the future direction of immunotherapeutic research.
\end{abstract}

Keywords adoptive cell transfer therapy; hepatocellular carcinoma; T cell; chimeric antigen receptor; immunotherapy

\section{Hepatocellular carcinoma is a major health challenge}

In recent years, cancer has become the leading cause of death and a major public health problem worldwide as a result of its rising morbidity and mortality rates. The latest cancer statistics show that 1735350 newly diagnosed cancer cases and 609640 cancer deaths will occur in the United States in 2018 [1]. The number of newly diagnosed cancer cases and cancer-related deaths in China will be several times higher than that in the United States given the former's massive and aging population. Lung cancer, liver cancer, and gastric cancer are the leading causes of cancer death in China [2].

Liver cancer is characterized by high malignancy degree and mortality rates, rapid progression, recurrence, and metastasis; hepatocellular carcinoma (HCC) accounts for the majority of liver cancer cases [3]. Currently, surgery is the most effective method for the treatment of $\mathrm{HCC}[4,5]$. The recurrence rate of $\mathrm{HCC}$ remains high after tumor

Received September 10, 2018; accepted December 20, 2018

Correspondence: Huijie Bian, hjbian@fmmu.edu.cn; Zhinan Chen, znchen@fmmu.edu.cn

${ }^{*}$ These authors contributed equally to this work. resection, and the five-year recurrence rate of patients with $\mathrm{HCC}$ is as high as $70 \%$ [6]. Moreover, only $20 \%$ to $30 \%$ of patients with HCC have the opportunity to adopt surgical treatment because most cases of this malignancy are accompanied by liver cirrhosis or are diagnosed at an advanced stage $[7,8]$. Conventional treatment regimens (e.g., chemotherapy, embolization, and radiotherapy) usually fail to considerably prolong the median overall survival of patients with advanced HCC [9]. The Food and Drug Administration (FDA) has approved several drugs that target HCC. These drugs, which are currently applied in clinical practice, can only exert a weak therapeutic effect. For example, sorafenib could only prolong the overall survival of patients with HCC for 2 months to 3 months and has a nonoptimistic clinical effect [10]. Lenvatinib is another targeted drug used as the first-line treatment for advanced HCC. Although phase III clinical trial data have shown that lenvatinib can prolong the overall survival of patients, it only increased overall survival by 1.3 months relative to that in the sorafenib group [11]. Regorafenib, a second-line drug for the treatment of advanced HCC, has been approved by the FDA for patients with HCC progressing to sorafenib treatment. The results of clinical trials showed that the median overall survival of patients with HCC in the regorafenib group was extended from 7.8 months to 10.6 
months relative to that in the placebo group [12]. Cabozantinib, a multitargeted small molecule inhibitor, and ramucirumab, an antagonistic anti-VEGFR2 monoclonal antibody, are second-line drugs applied for the treatment of advanced HCC and have been shown to improve the prognosis of patients [13]. Our team has developed $\left[{ }^{131} \mathrm{I}\right]$-labeled metuximab, a radioimmunoconjugate that is combined with radiofrequency ablation for the treatment of $\mathrm{HCC}$; our treatment method extended the median time to overall tumor recurrence by 7 months [14]. However, the median overall survival of patients with advanced HCC is still less than 1 year after treatment with current methods. Thus, new treatment strategies are urgently needed.

The liver is the largest solid organ in the human body. It can accept the dual blood supply of the portal vein and the hepatic artery. In contrast to classical lymphoid organs, such as the thymus and spleen, the liver consists of cells with nonimmunological primary functions but that still play a key immune role. In addition to the vast majority of parenchymal cells, the liver includes nonparenchymal cells, such as liver sinusoidal endothelial cells, Kupffer cells, hepatic stellate cells, and lymphocytes. The lymphocyte population localizes not only in the portal tract but is also distributed throughout the parenchyma. T cells, B cells, natural killer (NK) cells, and natural killer T (NKT) cells collectively constitute the lymphoid repertoire; the composition of the lymphoid repertoire enables the liver to participate in the immune regulation of the body [15]. Moreover, after the blood from the portal vein and the hepatic artery is transferred into the hepatic sinus, the deceleration of the blood flow rate enables antigens from the gut and systemic immunity to come into contact with the immune component in the liver to effectively regulate the immune response [16]. The dysregulation of the tightly regulated immune networks in the liver often results in the development of liver diseases, including chronic infections, autoimmune diseases, and tumors. Therefore, immunological methods for the treatment of HCC may provide improved therapeutic results. For example, the response rates of patients with advanced $\mathrm{HCC}$ to sorafenib and regofenib treatment were only $2 \%-3 \%$ and $7 \%$, respectively, whereas the objective response rates of patients with advanced HCC treated with nivolumab, a monoclonal antibody that disrupts programmed cell death protein-1 (PD-1) immune checkpoint signaling, were 15\%-20\% [17]. Clinical trial results indicate that other antibody drugs, such as pembrolizumab and durvalumab, have acceptable safety and clinical efficacy in the treatment of patients with HCC $[13,18]$. Although the clinical efficacy of immunological methods for the treatment of HCC is currently unsatisfactory, the immunotherapy strategy is one of the inevitable choices for the future treatment of HCC.

\section{Adoptive cell transfer therapy shows advantages in cancer therapy}

Cancer immunotherapy was considered as the first major breakthrough in 2013 by the Science magazine. Adoptive cell transfer therapy (ACT) is the most representative cancer immunotherapy method. In 1985, Rosenberg et al. initially demonstrated that the transfusion of autologous lymphokine-activated killer cells (LAK) could mediate objective cancer regression [19]. Three years later, another type of ACT based on tumor infiltrating lymphocytes (TILs) induced distinct tumor responses in patients with metastatic melanoma [20]. The application of a lymphodepletion regimen, such as nonmyeloablative cyclophosphamide and fludarabine, prior to TIL reinfusion greatly improved the efficiency of antitumor therapy [21,22]. The advent of ACT therapies that are based on cytokineinduced killer (CIK) cells and chimeric antigen receptor $\mathrm{T}$ cells (CAR-Ts) could prevent cancer recurrence and progression. Clinical trials on the applicability of TIL and CIK for the treatment of HCC are summarized in Table 1 [23-30].

ACT shows unique advantages over traditional treatment strategies. The basic principle of ACT is to improve the quantity and quality of cells that restrain the growth and survival of tumor cells to break the immune tolerance of tumor cells. Lymphocytes, the major effective cells of $\mathrm{ACT}$, are extracted from patients, modified or amplified in vitro, and then transferred to patients [31]. In contrast to antibodies or other targeted drugs, ACT is a living treatment that can be activated and proliferate in vivo with intensely durable antitumor effects [21]. ACT is considered as a highly individualized cancer therapy given that most effector cells are harvested autogenously from patients. Notably, because expanded or gene-modified effective cells can recognize and target tumor antigens, ACT is more specific than chemotherapy [32]. Circulating tumor cells and small residual lesions after operation can be effectively targeted and removed through ACT in vivo. Hence, ACT is not limited by clinical stage.

\section{Application of TILs in HCC treatment}

The TIL population represents an important cluster of antitumor effector cells that can be isolated from surgical tumor specimens. Given that T-cell receptors (TCRs) that are expressed on $\mathrm{T}$ cells that were isolated from TILs recognize diverse antigens, the antitumor effects of TILs are more intense than those of therapies targeting single antigens or mutations. Many previous studies have shown that TILs in HCC are rare but may have considerable implications for tumor recurrence and patient prognosis [33]. Patients with HCC and prominent lymphocyte infiltration who underwent surgical resection demonstrated 
Table 1 Summary of clinical trials on the applicability of TIL and CIK as HCC treatment strategies

\begin{tabular}{|c|c|c|c|c|c|}
\hline Cells used for ACT & $\begin{array}{l}\text { Patients }(n) \\
\text { total }\end{array}$ & $\begin{array}{l}\text { Patients }(n) \\
\text { treated with ACT }\end{array}$ & $\begin{array}{l}\text { Overall survival } \\
\text { (ACT vs. Control or } \\
\text { ACT alone) }\end{array}$ & $\begin{array}{l}\text { Recurrence rate (ACT } \\
\text { vs. Control or ACT } \\
\text { alone) }\end{array}$ & $\begin{array}{l}\text { Study } \\
\text { reference }\end{array}$ \\
\hline $\begin{array}{l}\text { Tumor-infiltrating } \\
\text { lymphocytes }\end{array}$ & 15 & 15 & $100 \%$ (14 months) & $20 \%$ (14 months) & {$[23]$} \\
\hline $\begin{array}{l}\text { Tumor-infiltrating } \\
\text { lymphocytes }\end{array}$ & 150 & 76 & $68 \%$ vs. $62 \%$ ( 5 years $)$ & $\begin{array}{l}59 \% \text { vs. } 77 \% \\
(4.4 \text { years })\end{array}$ & {$[24]$} \\
\hline $\begin{array}{l}\text { Cytokine-induced } \\
\text { killer cells }\end{array}$ & 132 & 66 & $\begin{array}{l}42.4 \% \text { vs. } 24.2 \% \\
\text { (3 years) }\end{array}$ & - & {$[25]$} \\
\hline $\begin{array}{l}\text { Cytokine-induced } \\
\text { killer cells }\end{array}$ & 127 & $41 / 43$ & $\begin{array}{l}37.9 \% / 38.1 \% \text { vs. } \\
36.9 \% \text { ( } 5 \text { years })\end{array}$ & $\begin{array}{l}73 \% / 72 \% \text { vs. } 76 \% \\
\text { (5 years) }\end{array}$ & {$[26]$} \\
\hline $\begin{array}{l}\text { Cytokine-induced } \\
\text { killer cells }\end{array}$ & 230 & 115 & - & $\begin{array}{l}39.5 \% \text { vs. } 49.1 \% \\
(4.4 \text { years })\end{array}$ & {$[27]$} \\
\hline $\begin{array}{l}\text { Cytokine-induced } \\
\text { killer cells }\end{array}$ & 85 & 45 & $\begin{array}{l}100 \% \text { vs. } 100 \% \\
(18 \text { months })\end{array}$ & $\begin{array}{l}15.6 \% \text { vs. } 40.0 \% \\
(18 \text { months })\end{array}$ & {$[28]$} \\
\hline $\begin{array}{l}\text { Cytokine-induced } \\
\text { killer cells }\end{array}$ & 83 & 42 & - & $\begin{array}{l}7.14 \% \text { vs. } 23.1 \% \\
\text { (1 year) }\end{array}$ & {$[29]$} \\
\hline $\begin{array}{l}\text { Cytokine-induced } \\
\text { killer cells }\end{array}$ & 146 & 72 & $\begin{array}{l}62.4 \% \text { vs. } 18.8 \% \\
(2 \text { years })\end{array}$ & - & {$[30]$} \\
\hline
\end{tabular}

ACT, adoptive cell transfer therapy.

reduced recurrence rates by $38.6 \%$ and increased five-year survival rates by $34.9 \%$ relative to those without substantial lymphocyte infiltration [34]. In a single randomized clinical trial, 150 patients with HCC showed improved recurrence-free survival after hepatic resection following adoptive immunotherapy using autologous lymphocytes activated with IL-2 in vitro [24]. However, TILs are difficult to isolate from the tumor tissues of patients with $\mathrm{HCC}$ and to amplify in vitro. In addition, only a few patients with HCC can tolerate lymphocyte deletion, which is essential for distinct antitumor effect, before TIL infusion [35].

\section{Application of CIK in HCC}

CIK cells are heterogeneous immune cell populations that are generated ex vivo through the expansion of PBMCs. The sequential addition of recombinant human IFN $\gamma$, antiCD3 monoclonal antibody, and recombinant human IL2 is essential for the acquisition of CIK cells through cell culture. After 14-21 days of incubation, CIK cells can be harvested and transfused into the patient to exert antitumor functions. Supplemented cytokines and antibodies not only improve the ability of PBMC to activate and proliferate in vitro but also increase the cytolytic activity of CIK cells against tumor cells. CIK cells consist of NKT cells $\left(\mathrm{CD} 3^{+} \mathrm{CD} 56^{+}\right)$, cytotoxic $\mathrm{T}$ cells $\left(\mathrm{CD} 3{ }^{+} \mathrm{CD} 56^{-}\right)$, and $\mathrm{NK}$ cells $\left(\mathrm{CD} 3{ }^{-} \mathrm{CD} 56^{+}\right)$, which are capable of recognizing and killing tumor cells directly [36]. Furthermore, activated cells exert a cytolytic effect against a variety of tumor cells independently of TCR-MHC class I interaction [37]. A large retrospective clinical study of 410 patients with HCC showed that the overall survival rates of the CIK adjuvant treatment group were higher than that of the surgery-alone group and revealed that patients with large lesions in the CIK group displayed drastically increased overall survival rates than those in the surgery-alone group [38].

Schmeel et al. summarized clinical results from 24 phase I and 21 phase II clinical trials of CIK treatment for different cancer diseases. Their results indicated that the overall survival of patients with HCC who underwent CIK cell treatment was prolonged by more than $40 \%$ compared with that of the control group [39]. However, a perfect prognostic system and additional guidance on large-scale clinical trials are still needed to be established to help clinicians determine whether patients with HCC can benefit from adjuvant CIK cell immunotherapy [40].

\section{CAR-T immunotherapy, a special kind of ACT}

CAR-T immunotherapy is a special type of ACT that utilizes gene engineering technology to modify $\mathrm{T}$ cells to perform antitumor functions [41]. The design and integration of a chimeric antigen receptor (CAR) into $\mathrm{T}$ cells to form CAR-T cells throughout the entirety of the immunotherapy process is the most critical technology of this treatment modality. At present, the most widely used CAR structure consists of a single-chain antibody extracellular domain that recognizes and binds specific antigens, an extracellular hinge region, a transmembrane region, and an intracellular domain that provides proliferation and activation signals. In contrast to the TCR structure on 
traditional $\mathrm{T}$ cells, this CAR structure is independent of major histocompatibility complex (MHC) antigen presentation, avoids the restriction of MHC molecules, and solves the immune escape problem of tumors attributed to the downregulation of MHC molecule expression [42]. In addition to some universal CAR-T treatments at the research stage, the most widely used CAR-T immunotherapy is a personalized cell therapy method, and each patient must complete the reinfusion treatment with their own immune cells that have been engineered in vitro. Typical CAR-T immunotherapy is mainly divided into the following five steps: the separation of peripheral blood mononuclear cells from patients, the integration of CARs into $\mathrm{T}$ cells, the cultivation and extensive expansion of CAR-T cells in vitro, the transfusion of CAR-T cells, and the strict monitoring of patients after cell reinfusion. Although CAR-T treatment is very expensive, it is a promising strategy for cancer treatment given its ability to kill tumor cells accurately and mild side effects.

CAR-T immunotherapy has achieved breakthrough results in the treatment of hematological malignancies, such as chronic lymphocytic leukemia, acute lymphocytic leukemia, and multiple myeloma [43,44]. Notably, Kymriah and Yescarta, two kinds of CAR-T therapeutic products for relapsed or refractory lymphoblastic leukemia and refractory large B-cell lymphoma, respectively, were approved by the FDA in 2017 [45,46]. Clinical trials on CAR-T therapy for solid tumors, such as breast cancer, colorectal cancer, HCC, and prostate cancer, have been performed [47]. Although the clinical trial data that could be obtained are limited, preclinical studies have demonstrated that CAR-T is a promising approach for the treatment of solid tumors. For example, CAR-T cells targeting disialoganglioside GD2 demonstrated a potent and long-lasting therapeutic effect and improved survival in mice with diffuse intrinsic pontine glioma orthotopic xenografts [48]. To date, an increasing number of clinical trials have been performed to illustrate the value of CAR-T cell therapy for solid tumors. Clinical trials on the applicability of CAR-T therapy for the treatment of HCC are summarized in Table 2. Antigens involving GPC3, ErB2, GD2, EGFR, PSMA, and MUC1 are targeted in CAR-T therapy for solid tumors $[47,49,50]$. As is the case in hematologic malignancies, the suitable target for solid tumors must be selected to avoid side effects resulting from on-target, off tumor toxicity [32].

Although no universal standard guide for the selection of antigen targets exists, the antigen that is expressed at high levels in tumor tissues and at low levels in normal tissues must be selected in consideration of the safety of CAR-T treatment and the scarcity of tumor-specific antigens. Specifically, the appropriate target can be selected in accordance with the degree of tumor differentiation and the reinfusion method used in CAR-T treatment. For example, the expression of some tumor-associated antigens drastically increases with the malignant progression of the tumor. The selection of a highly expressed antigen target for a particular grade of tumor is more rational than the broad-spectrum selection of an antigen target for a certain tumor. At present, in many clinical trials, CAR-T cells are returned to the patient through local administration for the treatment of solid tumors to ensure maximum safety. In addition to the selection of antigen targets that are expressed at high levels in tumor tissues, antigens that are expressed in low levels in local tissues should be preferred, and those that are expressed at low levels in distant tissues may be considered as secondary choices.

Currently, although CAR-T cell immunotherapy for solid tumors has become a research hotspot, clinical studies on the treatment of HCC have not been reported, and the achievements of preclinical studies are rare. GPC3, a member of the glypican family of heparin sulfate proteoglycans, is widely chosen in registered clinical trials on the applicability of CAR-T therapy for HCC treatment [51]. Gao et al. presented the first report on CAR-T cell therapy for HCC treatment. Their results indicated that $\mathrm{GPC}^{+}$HCC cells were effectively lysed by $\mathrm{T}$ cells expressing GPC3-targeted CAR (GPC3-CART). Notably, the lysis of $\mathrm{GPC}^{+} \mathrm{HCC}$ cells was positively correlated with the expression levels of GPC3 in tumor cells. Furthermore, GPC3-CART showed similar inhibitory abilities in vivo: the potent suppression of tumorigenesis in HCC subcutaneous xenograft models and the considerable prolongation of the survival of orthotopic-xenograft mice [9].

Another phase I clinical trial on cell immunotherapy aiming to explore the safety of CAR-T hepatic artery infusions (HAI) for unresectable carcinoembryonic antigen (CEA)-positive liver metastases demonstrated that increased neutrophil/lymphocyte ratios were indicative of poor outcomes for patients with cancer following CAR-T HAI [52]. A case reported by Morgan et al. illustrated the most serious adverse effect that occurred after the administration of $\mathrm{T}$ cells transduced with a CAR that recognizes ERBB2. In this case, a patient with colon cancer and liver metastases experienced respiratory distress shortly after receiving an intravenous infusion of $1 \times 10^{10}$ ERBB2-CART cells in $125 \mathrm{~mL}$ over $30 \mathrm{~min}$; the patient died 5 days later despite undergoing prompt treatment [53]. Another study on CEA-CART in a murine model of CEA-positive liver metastases revealed that liver myeloid-derived suppressor cells could inhibit CAR-T function [54]. These data collectively indicate that although GPC3-CART cell immunotherapy showed commendable efficacy, the toxic adverse effects of immune cell infusion and the immunosuppressive microenvironment in the liver are potentially important barriers to the application of CAR-T in HCC therapy. 
Table 2 Summary of clinical trials on the applicability of CAR-T therapy as a HCC treatment strategy

\begin{tabular}{|c|c|c|c|c|c|c|c|}
\hline $\begin{array}{l}\text { Clinical trial } \\
\text { identifier }\end{array}$ & Antigen & Phase & $\begin{array}{l}\text { Estimated } \\
\text { enrollment }\end{array}$ & Infusion & Doses & Sponsor & Status \\
\hline NCT02715362 & GPC3 & I/II & 30 & $\begin{array}{l}\text { Transcatheter } \\
\text { arterial infusion }\end{array}$ & $(1-10) \times 10^{6} / \mathrm{kg}$ & $\begin{array}{l}\text { Shanghai Gene } \\
\text { Chem Co., Ltd. }\end{array}$ & Recruiting \\
\hline NCT03130712 & GPC3 & $\mathrm{I} / \mathrm{II}$ & 10 & $\begin{array}{l}\text { Intratumor } \\
\text { injection }\end{array}$ & $(1-10) \times 10^{6}$ & $\begin{array}{l}\text { Shanghai Gene } \\
\text { Chem Co., Ltd. }\end{array}$ & Recruiting \\
\hline NCT03198546 & GPC3 & I & 30 & - & - & $\begin{array}{l}\text { Second Affiliated } \\
\text { Hospital of } \\
\text { Guangzhou } \\
\text { Medical } \\
\text { University }\end{array}$ & Recruiting \\
\hline NCT03146234 & GPC3 & - & 20 & $\begin{array}{l}\text { Intravenous } \\
\text { injection }\end{array}$ & $\begin{array}{l}\text { Self-controlled } \\
\text { dose escalation }\end{array}$ & Renji Hospital & Recruiting \\
\hline NCT03349255 & AFP & I & 18 & $\begin{array}{l}\text { Intravenous } \\
\text { infusion and } \\
\text { intrahepatic } \\
\text { artery infusion }\end{array}$ & - & $\begin{array}{l}\text { Aeon Therapeutics I } \\
\text { (Shanghai) Co., } \\
\text { Ltd. }\end{array}$ & Recruiting \\
\hline NCT02587689 & MUC1 & $\mathrm{I} / \mathrm{II}$ & 20 & - & - & $\begin{array}{l}\text { PersonGen } \\
\text { BioTherapeutics } \\
\text { (Suzhou) Co., Ltd. }\end{array}$ & Recruiting \\
\hline NCT02959151 & GPC3 & $\mathrm{I} / \mathrm{II}$ & 20 & $\begin{array}{l}\text { Vascular } \\
\text { interventional } \\
\text { therapy or } \\
\text { intratumor } \\
\text { injection }\end{array}$ & $\begin{array}{l}(1.25-4) \times 10^{7} \\
/ \mathrm{cm}^{3} \text { tumor bulk }\end{array}$ & $\begin{array}{l}\text { Shanghai } \\
\text { GeneChem Co., } \\
\text { Ltd. }\end{array}$ & Recruiting \\
\hline NCT03013712 & EpCAM & $\mathrm{I} / \mathrm{II}$ & 60 & $\begin{array}{l}\text { Vascular } \\
\text { interventional } \\
\text { mediated or } \\
\text { endoscopy } \\
\text { infusion }\end{array}$ & $(1-10) \times 10^{6} / \mathrm{kg}$ & $\begin{array}{l}\text { First Affiliated } \\
\text { Hospital of } \\
\text { Chengdu Medical } \\
\text { College }\end{array}$ & Recruiting \\
\hline NCT02905188 & GPC3 & I & 14 & - & $\begin{array}{l}1 \times 10^{7} / \mathrm{m}^{2} \\
3 \times 10^{7} / \mathrm{m}^{2} \\
1 \times 10^{8} / \mathrm{m}^{2} \\
3 \times 10^{8} / \mathrm{m}^{2} \\
1 \times 10^{9} / \mathrm{m}^{2}\end{array}$ & $\begin{array}{l}\text { Baylor College } \\
\text { of Medicine }\end{array}$ & Not yet recruiting \\
\hline NCT03084380 & GPC3 & I/II & 20 & $\begin{array}{l}\text { Transcatheter } \\
\text { arterial } \\
\text { chemoemboliza- } \\
\text { tion combined } \\
\text { with CAR-T } \\
\text { infusion }\end{array}$ & - & $\begin{array}{l}\text { Xinqiao Hospital } \\
\text { of Chongqing }\end{array}$ & Not yet recruiting \\
\hline NCT03302403 & GPC3 & - & 48 & $\begin{array}{l}\text { Intravenous } \\
\text { injection }\end{array}$ & $\begin{array}{l}\text { Self-controlled } \\
\text { dose escalation }\end{array}$ & $\begin{array}{l}\text { First Affiliated } \\
\text { Hospital of } \\
\text { Wenzhou Medical } \\
\text { University }\end{array}$ & Not yet recruiting \\
\hline NCT02723942 & GPC3 & $\mathrm{I} / \mathrm{II}$ & 60 & - & - & $\begin{array}{l}\text { Fuda Cancer } \\
\text { Hospital, } \\
\text { Guangzhou }\end{array}$ & Completed \\
\hline NCT02395250 & GPC3 & I & 13 & - & - & Renji Hospital & Terminated \\
\hline
\end{tabular}

GPC3, glypican-3; AFP, $\alpha$-fetoprotein; MUC1, mucin-1; EpCAM, epithelial cell adhesion molecule.

\section{Challenges and strategies of CAR-T immunotherapy for HCC treatment}

\section{Traffic and reinfusion manners}

CAR-T cells must be trafficked and infiltrate into tumor sites to exert their cytolytic effects. Intravenous injection is an effective approach for the reintroduction of CAR-T cells into patients with hematological malignancies. However, this approach is unfeasible for HCC treatment because of the relatively limited blood distribution of regional organs. Human liver tissues account for approximately $14 \%$ of the 
blood supply of the whole body, and only a small faction of blood is required to nourish the growth of liver neoplasms. CAR-T cells infused through intravenous flow with blood in the vessels rarely infiltrate the HCC site and may even severely damage the lungs and other normal organs because of their low antigen specificity [53]. In addition, HCC tumors that developed from liver fibrosis and cirrhosis are highly fibrotic and difficult to penetrate physically. These features complicate the infiltration of CAR-T cells into tumor sites; similarly, patients showed weak response to other immunotherapies (e.g., checkpoint inhibitors) [55].

Numerous studies focusing on the introduction of chemokines to the CAR structure to surmount the infiltration barrier have been conducted. Adachi et al. transferred the IL-17 and CCL19 genes to CAR-T cells to produce $7 \times 19$ CAR-T cells. The survival rates of tumorbearing DBA/2 mouse models treated with $7 \times 19$ CAR$\mathrm{T}$ cells reached almost $100 \%$, whereas that of models treated with conventional CAR-T treatment was only $30 \%$. The immunofluorescence technique was used to detect the number of immune cells in tumor tissues and revealed that $7 \times 19$ CAR-T cells can promote the infiltration of T cells and dendritic cells into tumor tissues effectively. In addition, IL-7 is necessary for increasing the proliferation and survival of $7 \times 19$ CAR-T cells and for achieving a good therapeutic effect on solid tumors [56]. Runx3, a key transcription factor that promotes $\mathrm{T}$-cell residency in nonlymphoid sites, has been recently identified and is a potentially essential cofactor of CAR-T cell therapy. The expression levels of Runx 3 and other tissue-residency gene-expression signatures drastically increased in tissueresident memory T cells but were low in circulating central memory T cells [57]. These studies provided new insights on the preferential infiltration of immune cells into solid tumor tissue.

Some other strategies can also be used to facilitate the infiltration of CAR-T cells into tumor tissues. Transcatheter arterial chemoembolization (TACE) is an interventional therapy that combines imaging diagnosis with clinical treatment and is the preferred method for the nonoperative treatment of liver cancer [58]. Given the adverse effects of intravenous injection on the treatment of $\mathrm{HCC}$, clinicians may transfuse CAR-T cells in an interventional manner. This approach can improve the efficiency of killer cell infiltration into tumor tissues and drastically reduce the occurrence of systemic side reactions. However, the determination of cell reinfusion doses for TACE remains problematic and depends on the sizes and numbers of hepatic tumors and individual differences. Thus, identifying the most effective and safe input dose may be a difficult task that must be tackled in the future.

\section{Tumor microenvironment and immune checkpoint inhibitors}

Previous studies have demonstrated that patients with HCC and prominent lymphocyte infiltration may exhibit reduced tumor recurrence and prolonged overall survival $[59,60]$. In addition, Flecken et al. revealed that the production of interferon- $\gamma$ was lower in $\mathrm{CD}^{+} \mathrm{T}$ cells derived from TIL than in those derived from intrahepatic lymphocytes and peripheral blood mononuclear cells [61]. These findings support the existence of a suppressive microenvironment that may inhibit the cytotoxic function of CAR-T cells in HCC.

The tumor environment in HCC comprises immunosuppressive stromal cells and molecules, including myeloid-derived suppressor cells; tumor-associated macrophages; regulatory T cells; immune checkpoint molecules; and other immune-inhibitory factors, such as adenosine and indoleamine 2, 3-dioxygenase [62,63]. All of these ingredients constitute a complex network that promotes tumor growth by exhausting $\mathrm{T}$ cells in the $\mathrm{HCC}$ microenvironment.

Immune checkpoint molecules, such as PD-1 and T-cell immunoglobulin domain and mucin domain protein-3 (TIM3), are currently considered as the key factors in the HCC microenvironment. Antibodies against one or more of these molecules can restore the functions of TIL in HCC [64]. Given that the cytotoxicity of CAR-T cells is reduced by immune checkpoint molecules, the combinations of CAR-T and immune checkpoint inhibitors might represent an effective strategy for HCC treatment. Nevertheless, the disruption of PD-1 in CAR-T cells by the CRISPR/Cas9 system may enhance antitumor functions in vivo and in vitro [65]. Likewise, other immune checkpoint molecules can also be disrupted by genome editing technology, which contributes to the treatment of $\mathrm{HCC}$.

\section{Main side effects of CAR-T}

CAR-T cell therapy has made great strides in the clinical treatment of hematological malignancies. However, fatal side effects have also occurred in clinical practice. In a typical case of CAR-T cell therapy, a patient with liver metastases suffered severe respiratory failure and ultimately died [53]. Neelapu et al. reviewed the toxic effects of CAR-T cell therapy. These toxic effects include cytokine-release syndrome (CRS), hemophagocytic lymphohistiocytosis, and CAR-T cell-related encephalopathy syndrome. The supervision of vital signs and serum biochemical indexes; imageological examination; and the preparation of first-aid medicine, such as tocilizumab, an anti-IL-6-receptor monoclonal antibody that alleviates the symptoms of CRS, are essential for patients receiving 
CAR-T cell infusion [66]. Reducing adverse events and maximizing the clinical efficiency of CAR-T cells are critical because side effects cannot be completely avoided.

\section{Conclusions}

ACT therapy brings hope for the treatment of cancer. Its success is crucial for the development of translational medicine and will accelerate the transfer of the results of cancer treatment research from the bench to the bedside. CAR-T therapy, the most promising ACT treatment, will inevitably provide breakthroughs in the treatment of solid tumors in the future. Considering the excellent antitumor effects of CAR-T, the heterogeneity of tumors, and the expensiveness of currently available treatments, the research and development of universal and individualized CAR-T therapeutic products are the future direction of CAR-T therapy. Preparing CAR-T cells targeting tumorassociated antigens that are expressed at high levels in tumor tissues and at low levels in other tissues is a viable option given the difficulties in screening tumor-specific antigens. The transformation of CAR-T cells that target tumor-associated antigens to maximize the avoidance of adverse reactions will be a future research hotspot. At the same time, given the heterogeneity of tumors, research on the preparation of CAR-T cells by using neoantigens (epitope-specific antigens produced by tumor cell mutations) for individualized tumor immunotherapy should not be stagnant. A comprehensive and feasible clinical solution with minimal adverse reactions must be developed to prolong the median overall survival of patients with advanced HCC. The optimal cell dose, rational infusion method, and appropriate treatment schedule are problems that require further exploration. Given the complexity of tumor immune mechanisms, CAR-T immunotherapy combined with other therapeutic methods may represent promising strategies for HCC. In addition, the establishment of immunologist-led, clinician-assisted multicenter tumor immunotherapy teams will greatly promote technological innovation and improve the clinical efficacy of immunotherapies for $\mathrm{HCC}$ in the future.

\section{Acknowledgements}

This work was supported by grants from the National Natural Science Foundation of China (Nos. 31571434, 81874155, and 81872482 ) and the National Science and Technology Major Project (No. 2015CB553701).

\section{Compliance with ethics guidelines}

Renyu Zhang, Zhao Zhang, Zekun Liu, Ding Wei, Xiaodong Wu, Huijie Bian, and Zhinan Chen declare no conflicts of interest. This manuscript is a review article and does not involve a research protocol requiring approval by the relevant institutional review board or ethics committee.

Open Access This article is distributed under the terms of the Creative Commons Attribution 4.0 International License (http:// creativecommons.org/licenses/by/4.0/), which permits unrestricted use, distribution, and reproduction in any medium, provided the appropriate credit is given to the original author(s) and the source, and a link is provided to the Creative Commons license, indicating if changes were made.

\section{References}

1. Siegel RL, Miller KD, Jemal A. Cancer statistics, 2018. CA Cancer J Clin 2018; 68(1): 7-30

2. Chen W, Zheng R, Baade PD, Zhang S, Zeng H, Bray F, Jemal A, Yu XQ, He J. Cancer statistics in China, 2015. CA Cancer J Clin 2016; 66(2): 115-132

3. Forner A, Reig M, Bruix J. Hepatocellular carcinoma. Lancet 2018; 391(10127): 1301-1314

4. Makarova-Rusher OV, Medina-Echeverz J, Duffy AG, Greten TF. The yin and yang of evasion and immune activation in HCC. J Hepatol 2015; 62(6): 1420-1429

5. Greten TF, Wang XW, Korangy F. Current concepts of immune based treatments for patients with HCC: from basic science to novel treatment approaches. Gut 2015; 64(5): 842-848

6. Désert R, Rohart F, Canal F, Sicard M, Desille M, Renaud S, Turlin B, Bellaud P, Perret C, Clément B, Lê Cao KA, Musso O. Human hepatocellular carcinomas with a periportal phenotype have the lowest potential for early recurrence after curative resection. Hepatology 2017; 66(5): 1502-1518

7. Galun D, Srdic-Rajic T, Bogdanovic A, Loncar Z, Zuvela M. Targeted therapy and personalized medicine in hepatocellular carcinoma: drug resistance, mechanisms, and treatment strategies. J Hepatocell Carcinoma 2017; 4: 93-103

8. Chen C, Li K, Jiang H, Song F, Gao H, Pan X, Shi B, Bi Y, Wang H, Wang H, Li Z. Development of T cells carrying two complementary chimeric antigen receptors against glypican-3 and asialoglycoprotein receptor 1 for the treatment of hepatocellular carcinoma. Cancer Immunol Immunother 2017; 66(4): 475-489

9. Gao H, Li K, Tu H, Pan X, Jiang H, Shi B, Kong J, Wang H, Yang S, $\mathrm{Gu}$ J, Li Z. Development of T cells redirected to glypican-3 for the treatment of hepatocellular carcinoma. Clin Cancer Res 2014; 20 (24): 6418-6428

10. Llovet JM, Ricci S, Mazzaferro V, Hilgard P, Gane E, Blanc JF, de Oliveira AC, Santoro A, Raoul JL, Forner A, Schwartz M, Porta C, Zeuzem S, Bolondi L, Greten TF, Galle PR, Seitz JF, Borbath I, Häussinger D, Giannaris T, Shan M, Moscovici M, Voliotis D, Bruix J; SHARP Investigators Study Group. Sorafenib in advanced hepatocellular carcinoma. N Engl J Med 2008; 359(4): 378-390

11. Kudo M, Finn RS, Qin S, Han KH, Ikeda K, Piscaglia F, Baron A, Park JW, Han G, Jassem J, Blanc JF, Vogel A, Komov D, Evans TRJ, Lopez C, Dutcus C, Guo M, Saito K, Kraljevic S, Tamai T, Ren $\mathrm{M}$, Cheng AL. Lenvatinib versus sorafenib in first-line treatment of patients with unresectable hepatocellular carcinoma: a randomised phase 3 non-inferiority trial. Lancet 2018; 391(10126): 1163-1173 12. Bruix J, Qin S, Merle P, Granito A, Huang YH, Bodoky G, Pracht 
M, Yokosuka O, Rosmorduc O, Breder V, Gerolami R, Masi G, Ross PJ, Song T, Bronowicki JP, Ollivier-Hourmand I, Kudo M, Cheng AL, Llovet JM, Finn RS, LeBerre MA, Baumhauer A, Meinhardt G, Han G; RESORCE Investigators. Regorafenib for patients with hepatocellular carcinoma who progressed on sorafenib treatment (RESORCE): a randomised, double-blind, placebocontrolled, phase 3 trial. Lancet 2017; 389(10064): 56-66

13. Llovet JM, Montal R, Sia D, Finn RS. Molecular therapies and precision medicine for hepatocellular carcinoma. Nat Rev Clin Oncol 2018; 15(10): 599-616

14. Bian H, Zheng JS, Nan G, Li R, Chen C, Hu CX, Zhang Y, Sun B, Wang XL, Cui SC, Wu J, Xu J, Wei D, Zhang X, Liu H, Yang W, Ding Y, Li J, Chen ZN. Randomized trial of $\left[{ }^{131} \mathrm{I}\right]$ metuximab in treatment of hepatocellular carcinoma after percutaneous radiofrequency ablation. J Natl Cancer Inst 2014; 106(9): dju239

15. Bogdanos DP, Gao B, Gershwin ME. Liver immunology. Compr Physiol 2013; 3(2): 567-598

16. Ringelhan M, Pfister D, O'Connor T, Pikarsky E, Heikenwalder M. The immunology of hepatocellular carcinoma. Nat Immunol 2018; 19(3): $222-232$

17. El-Khoueiry AB, Sangro B, Yau T, Crocenzi TS, Kudo M, Hsu C, Kim TY, Choo SP, Trojan J, Welling TH 3rd, Meyer T, Kang YK, Yeo W, Chopra A, Anderson J, Dela Cruz C, Lang L, Neely J, Tang H, Dastani HB, Melero I. Nivolumab in patients with advanced hepatocellular carcinoma (CheckMate 040): an open-label, noncomparative, phase $1 / 2$ dose escalation and expansion trial. Lancet 2017; 389(10088): 2492-2502

18. Zhu AX, Finn RS, Edeline J, Cattan S, Ogasawara S, Palmer D, Verslype C, Zagonel V, Fartoux L, Vogel A, Sarker D, Verset G, Chan SL, Knox J, Daniele B, Webber AL, Ebbinghaus SW, Ma J, Siegel AB, Cheng AL, Kudo M; KEYNOTE-224 investigators. Pembrolizumab in patients with advanced hepatocellular carcinoma previously treated with sorafenib (KEYNOTE-224): a non-randomised, open-label phase 2 trial. Lancet Oncol 2018; 19(7): 940-952

19. Rosenberg SA, Lotze MT, Muul LM, Leitman S, Chang AE, Ettinghausen SE, Matory YL, Skibber JM, Shiloni E, Vetto JT, Seipp CA, Simpson C, Reichert CM. Observations on the systemic administration of autologous lymphokine-activated killer cells and recombinant interleukin-2 to patients with metastatic cancer. N Engl J Med 1985; 313(23): 1485-1492

20. Rosenberg SA, Packard BS, Aebersold PM, Solomon D, Topalian SL, Toy ST, Simon P, Lotze MT, Yang JC, Seipp CA, Simpson C, Carter C, Bock S, Schwartzentruber D, Wei JP, White DE. Use of tumor-infiltrating lymphocytes and interleukin-2 in the immunotherapy of patients with metastatic melanoma. A preliminary report. N Engl J Med 1988; 319(25): 1676-1680

21. Rosenberg SA, Restifo NP. Adoptive cell transfer as personalized immunotherapy for human cancer. Science 2015; 348(6230): 62-68

22. Wong YNS, Joshi K, Pule M, Peggs KS, Swanton C, Quezada SA, Linch M. Evolving adoptive cellular therapies in urological malignancies. Lancet Oncol 2017; 18(6): e341-e353

23. Jiang SS, Tang Y, Zhang YJ, Weng DS, Zhou ZG, Pan K, Pan QZ, Wang QJ, Liu Q, He J, Zhao JJ, Li J, Chen MS, Chang AE, Li Q, Xia JC. A phase I clinical trial utilizing autologous tumor-infiltrating lymphocytes in patients with primary hepatocellular carcinoma. Oncotarget 2015; 6(38): 41339-41349

24. Takayama T, Sekine T, Makuuchi M, Yamasaki S, Kosuge T,
Yamamoto J, Shimada K, Sakamoto M, Hirohashi S, Ohashi Y, Kakizoe T. Adoptive immunotherapy to lower postsurgical recurrence rates of hepatocellular carcinoma: a randomised trial. Lancet 2000; 356(9232): 802-807

25. Yu X, Zhao H, Liu L, Cao S, Ren B, Zhang N, An X, Yu J, Li H, Ren $\mathrm{X}$. A randomized phase II study of autologous cytokine-induced killer cells in treatment of hepatocellular carcinoma. J Clin Immunol 2014; 34(2): 194-203

26. Hui D, Qiang L, Jian W, Ti Z, Da-Lu K. A randomized, controlled trial of postoperative adjuvant cytokine-induced killer cells immunotherapy after radical resection of hepatocellular carcinoma. Dig Liver Dis 2009; 41(1): 36-41

27. Lee JH, Lee JH, Lim YS, Yeon JE, Song TJ, Yu SJ, Gwak GY, Kim KM, Kim YJ, Lee JW, Yoon JH. Adjuvant immunotherapy with autologous cytokine-induced killer cells for hepatocellular carcinoma. Gastroenterology 2015; 148(7): 1383-1391.e6

28. Weng DS, Zhou J, Zhou QM, Zhao M, Wang QJ, Huang LX, Li YQ, Chen SP, Wu PH, Xia JC. Minimally invasive treatment combined with cytokine-induced killer cells therapy lower the short-term recurrence rates of hepatocellular carcinomas. J Immunother 2008; 31(1): 63-71

29. Pan CC, Huang ZL, Li W, Zhao M, Zhou QM, Xia JC, Wu PH. Serum $\alpha$-fetoprotein measurement in predicting clinical outcome related to autologous cytokine-induced killer cells in patients with hepatocellular carcinoma undergone minimally invasive therapy. Chin J Cancer 2010; 29(6): 596-602

30. Hao MZ, Lin HL, Chen Q, Ye YB, Chen QZ, Chen MS. Efficacy of transcatheter arterial chemoembolization combined with cytokineinduced killer cell therapy on hepatocellular carcinoma: a comparative study. Chin J Cancer 2010; 29(2): 172-177

31. Maus MV, Fraietta JA, Levine BL, Kalos M, Zhao Y, June CH. Adoptive immunotherapy for cancer or viruses. Annu Rev Immunol 2014; 32(1): 189-225

32. Gross G, Eshhar Z. Therapeutic potential of T cell chimeric antigen receptors (CARs) in cancer treatment: counteracting off-tumor toxicities for safe CAR T cell therapy. Annu Rev Pharmacol Toxicol 2016; 56(1): 59-83

33. Jochems C, Schlom J. Tumor-infiltrating immune cells and prognosis: the potential link between conventional cancer therapy and immunity. Exp Biol Med (Maywood) 2011; 236(5): 567-579

34. Wada Y, Nakashima O, Kutami R, Yamamoto O, Kojiro M. Clinicopathological study on hepatocellular carcinoma with lymphocytic infiltration. Hepatology 1998; 27(2): 407-414

35. Ma W, Wu L, Zhou F, Hong Z, Yuan Y, Liu Z. T cell-associated immunotherapy for hepatocellular carcinoma. Cell Physiol Biochem 2017; 41(2): 609-622

36. Mata-Molanes JJ, Sureda González M, Valenzuela Jiménez B, Martínez Navarro EM, Brugarolas Masllorens A. Cancer immunotherapy with cytokine-induced killer cells. Target Oncol 2017; 12 (3): 289-299

37. Morisaki T, Hirano T, Koya N, Kiyota A, Tanaka H, Umebayashi M, Onishi H, Katano M. NKG2D-directed cytokine-activated killer lymphocyte therapy combined with gemcitabine for patients with chemoresistant metastatic solid tumors. Anticancer Res 2014; 34(8): 4529-4538

38. Pan K, Li YQ, Wang W, Xu L, Zhang YJ, Zheng HX, Zhao JJ, Qiu HJ, Weng DS, Li JJ, Wang QJ, Huang LX, He J, Chen SP, Ke ML, 
Wu PH, Chen MS, Li SP, Xia JC, Zeng YX. The efficacy of cytokine-induced killer cell infusion as an adjuvant therapy for postoperative hepatocellular carcinoma patients. Ann Surg Oncol 2013; 20(13): 4305-4311

39. Schmeel LC, Schmeel FC, Coch C, Schmidt-Wolf IG. Cytokineinduced killer (CIK) cells in cancer immunotherapy: report of the international registry on CIK cells (IRCC). J Cancer Res Clin Oncol 2015; 141(5): 839-849

40. Pan QZ, Wang QJ, Dan JQ, Pan K, Li YQ, Zhang YJ, Zhao JJ, Weng DS, Tang Y, Huang LX, He J, Chen SP, Ke ML, Chen MS, Wicha MS, Chang AE, Zeng YX, Li Q, Xia JC. A nomogram for predicting the benefit of adjuvant cytokine-induced killer cell immunotherapy in patients with hepatocellular carcinoma. Sci Rep 2015; 5(1): 9202

41. Brudno JN, Kochenderfer JN. Chimeric antigen receptor T-cell therapies for lymphoma. Nat Rev Clin Oncol 2018; 15(1): 31-46

42. June CH, O'Connor RS, Kawalekar OU, Ghassemi S, Milone MC. CAR T cell immunotherapy for human cancer. Science 2018; 359 (6382): 1361-1365

43. Lee DW, Kochenderfer JN, Stetler-Stevenson M, Cui YK, Delbrook C, Feldman SA, Fry TJ, Orentas R, Sabatino M, Shah NN, Steinberg SM, Stroncek D, Tschernia N, Yuan C, Zhang H, Zhang L, Rosenberg SA, Wayne AS, Mackall CL. T cells expressing CD19 chimeric antigen receptors for acute lymphoblastic leukaemia in children and young adults: a phase 1 dose-escalation trial. Lancet 2015; 385(9967): 517-528

44. Hartmann J, Schüßler-Lenz M, Bondanza A, Buchholz CJ. Clinical development of CAR $\mathrm{T}$ cells-challenges and opportunities in translating innovative treatment concepts. EMBO Mol Med 2017; 9(9): 1183-1197

45. Liu Y, Chen X, Han W, Zhang Y. Tisagenlecleucel, an approved anti-CD19 chimeric antigen receptor T-cell therapy for the treatment of leukemia. Drugs Today (Barc) 2017; 53(11): 597-608

46. Vormittag P, Gunn R, Ghorashian S, Veraitch FS. A guide to manufacturing CAR T cell therapies. Curr Opin Biotechnol 2018; 53: $164-181$

47. Di S, Li Z. Treatment of solid tumors with chimeric antigen receptor-engineered $T$ cells: current status and future prospects. Sci China Life Sci 2016; 59(4): 360-369

48. Mount CW, Majzner RG, Sundaresh S, Arnold EP, Kadapakkam M, Haile S, Labanieh L, Hulleman E, Woo PJ, Rietberg SP, Vogel H, Monje M, Mackall CL. Potent antitumor efficacy of anti-GD2 CAR $\mathrm{T}$ cells in $\mathrm{H} 3-\mathrm{K}_{2} 7 \mathrm{M}^{+}$diffuse midline gliomas. Nat Med 2018; 24 (5): 572-579

49. Fesnak AD, June CH, Levine BL. Engineered T cells: the promise and challenges of cancer immunotherapy. Nat Rev Cancer 2016; 16 (9): 566-581

50. Zhang BL, Qin DY, Mo ZM, Li Y, Wei W, Wang YS, Wang W, Wei YQ. Hurdles of CAR-T cell-based cancer immunotherapy directed against solid tumors. Sci China Life Sci 2016; 59(4): 340-348

51. Jiang Z, Jiang X, Chen S, Lai Y, Wei X, Li B, Lin S, Wang S, Wu Q, Liang Q, Liu Q, Peng M, Yu F, Weng J, Du X, Pei D, Liu P, Yao Y, Xue P, Li P. Anti-GPC3-CAR T cells suppress the growth of tumor cells in patient-derived xenografts of hepatocellular carcinoma. Front Immunol 2017; 7: 690

52. Saied A, Licata L, Burga RA, Thorn M, McCormack E, Stainken BF, Assanah EO, Khare PD, Davies R, Espat NJ, Junghans RP, Katz SC. Neutrophil:lymphocyte ratios and serum cytokine changes after hepatic artery chimeric antigen receptor-modified T-cell infusions for liver metastases. Cancer Gene Ther 2014; 21(11): 457-462

53. Morgan RA, Yang JC, Kitano M, Dudley ME, Laurencot CM, Rosenberg SA. Case report of a serious adverse event following the administration of $T$ cells transduced with a chimeric antigen receptor recognizing ERBB2. Mol Ther 2010; 18(4): 843-851

54. Burga RA, Thorn M, Point GR, Guha P, Nguyen CT, Licata LA, DeMatteo RP, Ayala A, Joseph Espat N, Junghans RP, Katz SC. Liver myeloid-derived suppressor cells expand in response to liver metastases in mice and inhibit the anti-tumor efficacy of anti-CEA CAR-T. Cancer Immunol Immunother 2015; 64(7): 817-829

55. Lim WA, June $\mathrm{CH}$. The principles of engineering immune cells to treat cancer. Cell 2017; 168(4): 724-740

56. Adachi K, Kano Y, Nagai T, Okuyama N, Sakoda Y, Tamada K. IL7 and CCL19 expression in CAR-T cells improves immune cell infiltration and CAR-T cell survival in the tumor. Nat Biotechnol 2018; 36(4): 346-351

57. Milner JJ, Toma C, Yu B, Zhang K, Omilusik K, Phan AT, Wang D, Getzler AJ, Nguyen T, Crotty S, Wang W, Pipkin ME, Goldrath AW. Runx3 programs $\mathrm{CD}^{+} \mathrm{T}$ cell residency in non-lymphoid tissues and tumours. Nature 2017; 552(7684): 253-257

58. Fako V, Wang XW. The status of transarterial chemoembolization treatment in the era of precision oncology. Hepat Oncol 2017; 4(2): $55-63$

59. Unitt E, Marshall A, Gelson W, Rushbrook SM, Davies S, Vowler SL, Morris LS, Coleman N, Alexander GJ. Tumour lymphocytic infiltrate and recurrence of hepatocellular carcinoma following liver transplantation. J Hepatol 2006; 45(2): 246-253

60. Yoong KF, McNab G, Hübscher SG, Adams DH. Vascular adhesion protein-1 and ICAM-1 support the adhesion of tumor-infiltrating lymphocytes to tumor endothelium in human hepatocellular carcinoma. J Immunol 1998; 160(8): 3978-3988

61. Flecken T, Schmidt N, Hild S, Gostick E, Drognitz O, Zeiser R, Schemmer P, Bruns H, Eiermann T, Price DA, Blum HE, NeumannHaefelin C, Thimme R. Immunodominance and functional alterations of tumor-associated antigen-specific $\mathrm{CD} 8^{+} \mathrm{T}$-cell responses in hepatocellular carcinoma. Hepatology 2014; 59(4): 1415-1426

62. Prieto J, Melero I, Sangro B. Immunological landscape and immunotherapy of hepatocellular carcinoma. Nat Rev Gastroenterol Hepatol 2015; 12(12): 681-700

63. Joyce JA, Fearon DT. T cell exclusion, immune privilege, and the tumor microenvironment. Science 2015; 348(6230): 74-80

64. Zhou G, Sprengers D, Boor PPC, Doukas M, Schutz H, Mancham S, Pedroza-Gonzalez A, Polak WG, de Jonge J, Gaspersz M, Dong H, Thielemans K, Pan Q, JNM IJ, Bruno MJ, Kwekkeboom J. Antibodies against immune checkpoint molecules restore functions of tumor-infiltrating $\mathrm{T}$ cells in hepatocellular carcinomas. Gastroenterology 2017; 153(4): 1107-1119.e10

65. Ren J, Liu X, Fang C, Jiang S, June CH, Zhao Y. Multiplex genome editing to generate universal CAR T cells resistant to PD1 inhibition. Clin Cancer Res 2017; 23(9): 2255-2266

66. Neelapu SS, Tummala S, Kebriaei P, Wierda W, Gutierrez C, Locke FL, Komanduri KV, Lin Y, Jain N, Daver N, Westin J, Gulbis AM, Loghin ME, de Groot JF, Adkins S, Davis SE, Rezvani K, Hwu P, Shpall EJ. Chimeric antigen receptor T-cell therapy — assessment and management of toxicities. Nat Rev Clin Oncol 2018; 15(1): 4762 